\title{
Role of Microfinance in Employment Generation: A Case Study of Microfinance Program of Paschimanchal Grameen Bikash Bank
}

\author{
Hari Prasad Pathak \\ Mukunda Gyawali
}

\begin{abstract}
This research study focuses on role of microfinance program in creation of enterprise and employment generation. In the Nepalese context various microfinance programs have been running with the aims of socio-economic empowerment, mobilization of internal resources, creation of awareness and generation of self-employment targeting the rural poor. Microfinance has been one of the few effective tools for poverty reduction over the past years. It has been revealed that the loans have been mostly invested on small scale business, livestock and other agro-based enterprises. The study shows that micro finance program has been helpful to create enterprises and generate employment.
\end{abstract}

Keywords: microfinance, micro enterprise, employment

\section{Introduction}

The proper mobilization of domestic resources is one of the key factors in the economic development of a country. Similarly, integrated and speedy development of the country is only possible when competitive and reliable financial institution services are reached and operated to every corner of the country. Financial institutions have vital roles in the process of economic development. Financial performance, especially of microfinance institutions has long term impact not only on their growth and sustainability but also on the economic development of the country.

Micro finance program has different modalities. Some are community based such as saving and credit cooperatives and some are on priority sectors which include agriculture, small industries and services which are implemented through the financial institutions. Micro finance refers to small scale financial services provided to the people who farm or herb, who operate small or micro enterprises, where goods and services are produced, recycled, repaired or traded. Lack of access to finance is a major problem for microentrepreneurs to start up or to scale up the enterprises. Supporting only with managerial 
aspect such as entrepreneurial qualities development, viable enterprises selection, market access, technology and infrastructure would not be enough unless access to the credit is made possible. Many institutions in Nepal provide technical and vocational skill training to large number of people every year. No doubt, learning a simple skill such as tailoring, carpentry and barber is often sufficient to the trainees to start earning money. But in many cases, skill training alone does not prepare a person to start the enterprises. Credit facility and knowledge of managing business are equally important factors. To address such problems micro finance program - group formation, enhancement, awareness and credit facilities has become an effective means of intervention.

Paschimanchal Grameen Bikash Bank (PGBB) was established as a regional rural development bank in 1995 through a joint collaboration of the government of Nepal, Nepal Rastra Bank, six commercial banks, members of the bank and staff of the bank to serve poor and deprived people of the Western Development Region. Modelled on the Grameen Bank methodology, the mission of PGBB is to generate self-employment through microcredit to the rural poor at their doorstep to reduce poverty level in the western region of Nepal. The bank has been concentrating its efforts to alleviate the hardship and sufferings of the rural people of the western region of Nepal.

The main objective of the bank is to alleviate poverty of the rural poor through credit delivery system. The unique features of the bank are area approach, well defined target group, group guarantee lending approach, no physical collateral requirement and disbursement of loan at the center.

Rupandehi district lies in western development region of the country. The district is bordered with Nawalparasi district in the east, Kapilbastu in the west, Palpa in the north and Utterpardes State of India in the south. The total surface area of the district is 141340 hector with altitude ranging from $95 \mathrm{~m}$ to $1219 \mathrm{~m}$ above sea level. There are 6 major land use types practiced by the people of Rupandehi, of which the dominant land use type is cultivation $68.03 \%$ followed by forest $21.56 \%$. Since the district is under the Terai region, very little amount of mountain and Rocky cliff is available i.e. $0.29 \%$. Politically the district is divided into 7 Ilakas, 69 VDCs and 2 municipalities.

This study has been confined on the coverage area of Pashimanchal Grameen Bikash Bank, Semlar Branch Office which includes six VDCs and one municipality in Rupandehi district. It has focused on the role of microfinance program to create employment. 


\section{Objective of the Study}

Economic liberalization policy of the government has encouraged the establishment and growth of the financial institutions in the country. In this context, 21 grameen bikash banks/micro finance institutions have been established so far. With the growing number of micro finance institutions, people are benefited from such institutions. The major objective of the all microfinance programs is to enhance the deprived groups socially and economically. In this context, the objective of this study was to assess the role of micro finance in micro enterprises creation and employment generation.

\section{Methodology of the Study}

The center of attention of this study is the role of micro finance in employment generation. Therefore, descriptive and analytical research design has been adopted. Data required to carry out this study were basically obtained from primary source conducting field survey, direct interview and observation. However, secondary source of information were also used for the study and they were collected from the official documents, journals, published and unpublished dissertations, bulletins, related website and annual progress reports of Paschimanchal Grameen Bikash Bank. There were altogether 1360 members in 51 recognized centres of Paschimanchal Grameen Bikas Bank till December 2010 under its Micro Finance Program. These 1360 members were the population of this study. Out of total population of 1360 members 115 members were randomly selected as the sample size for the purpose of this study. Quantitative analysis tools were applied to assess the role of micro finance in employment generation and economic input of micro finance; and qualitative indicators are used to assess the socio-economic empowerment of women through micro finance. Qualitative information is based on observational perception.

\section{Analysis and Interpretation}

One of the most important objectives of this study was to find out the role of microfinance program on creation of enterprise and employment generation. It has been found that the purpose of loan taking of the respondents was to start a small scale business. Micro finance program (group formation, enhancement, awareness and credit facilities) of Paschimanchal Grameen Bikas Bank has been remained helpful for the poorest people to start their own micro enterprises. Data presented below shows the purpose of loan taking, sector wise business creation with employment generation. The study shows that the age group of people involved in taking micro finance facility are 20 to 60 years. $42 \%$ are in the age group of 31 years to 40 years. $76 \%$ of the respondents are below S.L.C. or merely literate. 


\subsection{Loan Taking Status of Sample Clients}

The sample clients have obtained loan mainly in the following two areas: (i) micro business loan and (ii) micro enterprises loan. Loan lending for small scale business such as retail store, hotel and service centers is categorized as micro business loan. Loan lending for manufacturing enterprises is categorized as micro enterprises loan. Discussion with the clients and Paschimanchal Grameen Bikas Bank field staff reveals that most of the clients have been paying back their loans in time.

Table 1 reveals that out of 115 respondents 102 respondents have been taking loan during the last five years. The limit of loan amount of PGBB micro finance program is up to Rs 90,000 per person. Total number of respondents taking loan of Rs. 10,000 to 20,000 is $36(35 \%)$. Similarly 21 (21\%) respondents have taken loan amount of Rs. 21,000 to 30,$000 ; 31(30 \%)$ respondents Rs. 31,000 to 40,000 and only 4 (4\%) respondents has been taking loan of Rs. 61,000 to 90,000 .

Table 1: Current Status of Loan

\begin{tabular}{|c|l|c|c|}
\hline S.No. & Loan Amount (in Rs.) & No. of Respondents & Percentage \\
\hline 1 & $10,000-20,000$ & 36 & $35 \%$ \\
\hline 2 & $21,000-30,000$ & 21 & $21 \%$ \\
\hline 3 & $31,000-40,000$ & 31 & $30 \%$ \\
\hline 4 & $41,000-50,000$ & 5 & $5 \%$ \\
\hline 5 & $51,000-60,000$ & 5 & $5 \%$ \\
\hline 6 & $61,000-90,000$ & 4 & $4 \%$ \\
\hline & Total & 102 & $100 \%$ \\
\hline
\end{tabular}

Source: Field Survey, 2010

It is revealed from Table 1 that a largest number of respondents have taken lowest amount of loan and vice versa. It is $35 \%$ of the respondents who have taken loan of Rs. 10,000 to 20,000 and only $4 \%$ of the respondents have taken loan amount Rs. 61,000 to 90,000 . It is found that with the increased of the loan amount there is decreased in the number of the person taking loan.

\subsection{Business Start Up}

It has been found that out of 115 respondents, 93 respondents have created different kinds of business which indicates business start up percentage is 80.86 while 22 $(19.14 \%)$ respondents have not started any business. Therefore, it could be concluded that 
microfinance services have contributed towards generating self-employment and uplifting economic status of the participants of the micro credit program.

Table 2: Enterprise Creation

\begin{tabular}{|c|c|c|c|}
\hline S.No. & Sector wise Enterprises & $\begin{array}{l}\text { No. of Enterprise } \\
\text { Created }\end{array}$ & Percentage \\
\hline 1 & $\begin{array}{l}\text { Agro based enterprises (vegetables and } \\
\text { fruits) }\end{array}$ & 6 & 6.45 \\
\hline 2 & Livestock (poultry, goat and pig) & 17 & 18.27 \\
\hline 3 & $\begin{array}{l}\text { Manufacturing Industries (furniture, } \\
\text { food processing, and garment) }\end{array}$ & 4 & 4.30 \\
\hline 4 & Trade (grocery, cosmetic) & 44 & 47.31 \\
\hline 5 & $\begin{array}{l}\text { Service (beauty parlor, sewing, photo } \\
\text { studio and hotel/restaurant) }\end{array}$ & 22 & 23.67 \\
\hline & Total & 93 & 100 \\
\hline
\end{tabular}

Source: Field Survey, 2010

\section{Fig. 1: Sectorwise Enterprise Creation}

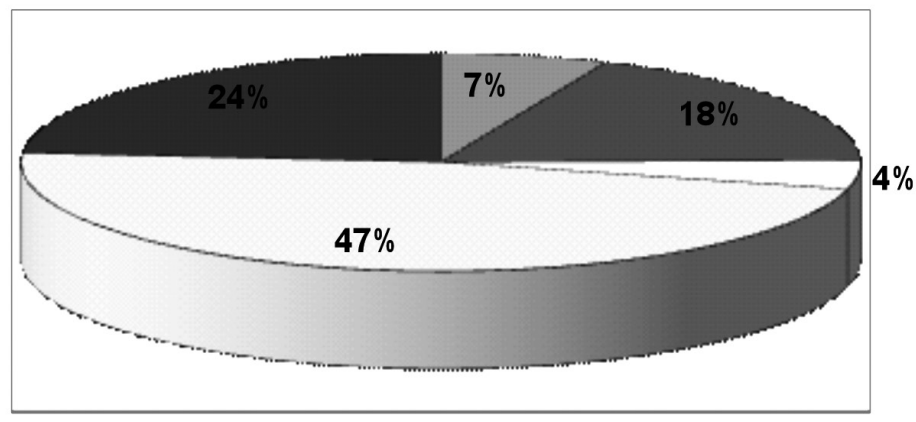

口Agro

口Livestock

口Manufacture

口Trade

-Service

The data in Table 2 gives the impression that it is consistent with the notion of microfinance program as it clearly shows that the program has provided micro finance for agriculture production, small scale business and livestock development. Figure 1 and Table 2 show that among the respondents who have started agro based micro businesses 
such as vegetables, fruits, and other cash crops are 6 (6.45\%). Similarly, 17 (18.27\%) have started livestock micro-business such as poultry, goat and pig rising and 22 (23.67 $\%$ ) started service business such as hotel/restaurant, beauty parlor, barber, photo studio and tailoring. Manufacturing micro industries such as furniture, garment, food processing have been started by 4 (4.3\%). A good number of respondents 44 (47.31\%) have adopted trading business after obtaining micro credit loan from the PGGB's micro finance program.

\subsection{Employment Generation on Sector-wise Enterprises}

The most important step to reduce poverty is to create employment and provide income generating opportunity for the poor. The prime objective of people to participate on the microfinance program is to get access to credit fund so that they could start micro-business and create employment for themselves. One of the major objectives for microfinance program is to create self-employment at local level. In the developing countries micro enterprises play the vital role in employment generation. Discussion with the women clients revealed that their husbands are also involved in the work they started from the borrowed fund. In some cases where women have invested for business have created employment for up to four persons of the family.

Table 3: Employment Generation Details

\begin{tabular}{|c|c|c|c|c|c|c|c|c|c|}
\hline \multirow[t]{2}{*}{$\begin{array}{l}\mathbf{S} \\
\mathbf{N}\end{array}$} & \multirow[t]{2}{*}{$\begin{array}{l}\text { Sector wise } \\
\text { Enterprise }\end{array}$} & \multicolumn{3}{|c|}{$\begin{array}{c}\text { Full Time } \\
\text { Employment }\end{array}$} & \multicolumn{3}{|c|}{$\begin{array}{c}\text { Part Time } \\
\text { Employment }\end{array}$} & \multirow[t]{2}{*}{ Total } & \multirow[t]{2}{*}{$\%$} \\
\hline & & Dalit & Janajat & Other & Dalit & Janajati & Other & & \\
\hline 1 & $\begin{array}{l}\text { Agro based } \\
\text { Enterprises }\end{array}$ & 4 & 3 & 1 & 2 & 1 & 1 & 12 & 8.63 \\
\hline 2 & Livestock & 6 & 5 & 3 & 2 & -- & 1 & 17 & 12.23 \\
\hline 3 & $\begin{array}{l}\text { Manufacture } \\
\text { Industries }\end{array}$ & 2 & 3 & 5 & 2 & 1 & 2 & 15 & 10.79 \\
\hline 4 & Trade & 12 & 11 & 17 & 6 & 3 & 4 & 53 & 38.13 \\
\hline 5 & Service & 6 & 13 & 13 & 2 & 6 & 2 & 42 & 30.22 \\
\hline \multicolumn{2}{|c|}{ Total } & 30 & 35 & 39 & 14 & 11 & 10 & 139 & 100 \\
\hline \multicolumn{10}{|c|}{$\begin{array}{c}\text { Dalit }=44, \text { Janajati }=46 \text { and other }=49 \text { Total full time employment }=104 \text { Part time }=35 \\
\text { Average employment per enterprises }=139 / 93=1.5\end{array}$} \\
\hline
\end{tabular}

Source: Field survey 2011. 
The data in Table 3, shows that 139 persons have been getting employment in 93 micro enterprise created by the rural people after involving in the PGBB Micro Finance Program. Out of 139, 36 persons are engaged part timely and 103 persons have full employment. According to ethnicity 44 (31\%) persons from Dalit, 46 (33\%) persons from Janajati and 49 (36\%) persons from others (Brahmin, Chhetri) have been getting employment. Maximum number 53(38.13\%) of employment has been generated from the trade and business which includes grocery, cosmetic etc and only few i.e. 12 (8.63\%) employment has been generated from agro based enterprise.

\section{Findings and Conclusions}

Out of 115 respondents, 102 respondents have been taking loan during the last five year for micro business startup. Similarly 93 respondents have created different kinds of business with the help of micro finance program. It indicates that business startup rate is $80.86 \%$. It shows that microfinance services have contributed towards generating own income from small scale business, agriculture and livestock holding thereby reducing the daily wages based labour. Micro enterprises are the main source of self-employment. The survey has revealed that, this program has created average employment for 1.5 persons from an enterprise. 35 respondents (30\%) have engaged part timely and 104 (90\%) have been getting full time employment in different business sector operated through the intervention of micro-credit program.

The micro finance program launched by PGBB has positive impact and vital role in enterprises creation and employment generation. It has been found to be an instrumental in starting micro enterprises. Moreover, the loans provided by micro-finance program have been mostly invested to operate small retail shops like grocery, cosmetic, furniture, foodprocessing; to run service industries like - tailoring, beauty parlour, photo studio and hotel/ restaurant and to carry out agro-based enterprises like vegetable farming, poultry farming, pig farming and goat farming. The major objective for microfinance program to create selfemployment at local level through micro and small level enterprises has been found to be successful.

It has been found that the intervention of PGBB's micro finance program has remained effective to start micro enterprises in the rural areas. The employment creation rate is 1.5 persons per enterprise. In the case of micro enterprise, it should be taken as satisfactorily, as one could not expect high employment from an undersized enterprise. 


\section{BIBLIOGRAPHY}

Bhattarai, B. (2005). Micro credit and employment and livelihood security scheme for poor women: Case Study of Dhapakhel VDC, Kathmandu. Unpublished master's thesis, T.U.

Bhattarai, P. (2061). The Nepalese financial system. Kathmandu: Asmita Books Publisher and Distributors.

CMF. (2004). An overview of the microfinance sector in Nepal. Kathmandu: Center for Microfinance, [online]. Available: <http://www.cmfnepal.org> (2011, March 8)

Joshi, B. (2004). Impact of Grameen Bikas Bank on income generation of rural women in Butwal. Unpublished master's thesis, Tribhuvan University.

Katsuma, Y. (1997). The role of credit in microenterprise development. Banco Solidario's microfinance services for the small-scale manufacturing by low-income people in Cochabamba, Bolivia. Ph. D. Thesis, University of Wisconsin, Madison.

National Planning Commission (NPC) (2007). Interim plan 2007-2012. Kathmandu: NPC. 